\title{
Satisfaction with the support received by parents of children with disabilities and the diversity of parental behaviour towards the child
}

\begin{abstract}
Kamil Kuracki, Satisfaction with the support received by parents of children with disabilities and the diversity of parental behaviour towards the child. Interdisciplinary Contexts of Special Pedagogy, no. 26, Poznań 2019. Pp. 191-215. Adam Mickiewicz University Press. ISSN 2300-391X. e-ISSN 2658-283X. DOI: https:/ / doi.org/10.14746/ ikps.2019.26.09
\end{abstract}

Raising, caring and rehabilitation of children with disabilities and developmental disorders is a serious challenge for their parents, because everyday situations associated with fulfilling parental duties generate a lot of various stress factors. Hence, receiving various kinds of social support seems to be an important factor affecting the well-being of parents. Thanks to this form of aid, it is possible to deal with a difficult situation and to reduce the disorder in family life. Moreover, the received support can significantly affect the parent-child relationship. This is particularly important in the context of reducing unfavourable behaviour and to intensify constructive parenting behaviour.

The main aim of the study was to recognise the type of aid provided to parents of disabled children and to determine the relationship between the support received by parents and the development of the parent-child relationship. The research group consisted of 66 parents of preschool children with disabilities and 40 parents of children without disabilities. The tools used in the research were: the Parent Behavior Inventory by M.C. Lovejoy, R. Weis, E. O'Hare \& E.C. Rubin, the Parent Cognition Scale by J.D. Snarr, A.M.S. Slep \& V.P. Grande and the Parents' Questionnaire by Agnieszka Dłużniewska. The study was conducted according to the correlation model.

KEY WORDS: Support for parents, parent-child relationship, children with disabilities 


\section{Introduction}

Parents raising children with disabilities frequently experience many difficulties related to various aspects of life. This fact is confirmed by numerous scientific studies conducted in Poland and abroad, proving that families of children with developmental difficulties are threatened by decidedly many more stress factors as compared to families of children developing correctly ${ }^{1}$. These factors, frequently not without influence on developing parental behaviour with respect to the child, may be related to a lack of efficient aid by medical and rehabilitation facilities, lack of social support from the closest family, neighbours and acquaintances, as well as unsatisfactory operation of the state's social policy or the stereotypical social attitudes towards their children observed on a daily basis. It is clear that it is difficult for parents not to see signs of emotional attachment by the child, in particular in the form of spontaneous expression of feelings towards parents or caretakers, and uncertainty as to the future of the child, the organisation of family life, the financial situation of the family and the possibility of achievement of own life goals and professional development that emerge in many situations. In many cases, a child's disability constitutes a factor that significantly destabilises the family life and necessitates the reorganisation of duties of the individual family members with respect to their previous order. ${ }^{2}$ The emerging feeling of

${ }^{1}$ N.O. Davis, A.S. Carter, Parenting stress in mothers and fathers of toddlers with autism spectrum disorders: Associations with child characteristic, "Journal of Autism and Developmental Disorders" 2008, no. 38(7), p. 1278-1291; A. Estes, J. Munson, G. Dawson, E. Koehler, X.H. Zhou, R. Abbot, Parenting stress and psychological functioning among mothers of preschool children with autism and developmental delay, "Autism” 2009, no. 13(4), pp. 375-387; E. Pisula, D. Noińska, Stres rodzicielski i percepcja doświadczeń związanych $z$ opieka nad dzieckiem u rodziców dzieci $z$ autyzmem uczestniczących w różnych formach terapii, "Psychologia rozwojowa" 2011, no. 3, pp. 75-88; L.M. Silva, M. Schalock, Autism parenting stress index: Initial psychometric evidence, "Journal of Autism and Developmental Disorders" 2012, no. 42(4), pp. 566-574.

2 Ł. Koperski, Rodzina dziecka z niepetnosprawnościq a wsparcie społeczne, [in:] Zasoby rodziny. Wychowanie, Poradnictwo, Praca socjalna, ed. by E. Czerka-Fortuna, 
the lack of specialist knowledge and skills in the area of support for the disabled child as well as the parents' conviction about the minor chances for effectiveness of rehabilitation may also turn out to be a significant burden for the parents.

\section{Theoretical basis for the research}

Situations emotionally burdening the parents of children with development disorders may stem from the limited possibility of contact with the child caused by flaws in communication, and also due to the child presenting a lot of behaviour that escapes adaptation, in light of which parents might feel lost, powerless and helpless. This is proven, among others, by research by Monique Seymour, Catherine E. Wood, Rebecci Giallo et al. ${ }^{3}$, conducted on a group of mothers of children with ASD, which showed significant relations between problematic behaviour patterns of children and the stress experienced by mothers. The study showed that difficult behaviour patterns of a child translate to increases in mother fatigue, and, as a consequence, to them implementing inefficient strategies of coping with stress - frequently focused on emotions, and not on the problem at hand. Such a style of coping, in light of the results of many empirical analyses, may directly translate to the generation of diverse behaviour patterns against own children that prevent adaptation ${ }^{4}$, in literature placed along the continuum be-

K. Kmita-Zaniewska, A. Zbierzchowska, Wydawnictwo Naukowe Katedra, Gdańsk 2016, pp. 156-177.

${ }^{3}$ M. Seymour, C.E. Wood, R. Giallo, R. Jellett, Fatigue, Stress and Coping in Mothers of Children with an Autism Spectrum Disorder, "Journal of Autism \& Developmental Disorders" 2013, no. 43, pp. 1547-1554.

${ }^{4}$ L.E. Smith, M.M. Seltzer, H. Tager-Flusberg, J.S. Greenberg, A.S. Carter, A Comparative Analysis of Well-Being and Coping among Mothers of Toddlers and Mothers of Adolescents with ASD, "Journal of Autism and Developmental Disorders" 2008, no. 38(5), pp. 876-889; A. Ghasempour, E. Akbari, M. Taghipour, Z. Azimi, E. Refaghat, Comparison of psychological well-being and coping styles in mothers of deaf and normally-hearing children, "Audiology" 2012, no. 21(4), pp. 51-59. 
tween enmity and compulsion..$^{5}$ Moreover, it must be underscored that stress frequently accompanying families raising children with disabilities is long-term and cumulative in nature.

The influence of internalising and externalising behaviour of ill children and children with development disabilities on the increase of experienced parental stress is also shown by studies by Marieke Verkleij, Erik J. van de Griendt, Vivian Colland et al. ${ }^{6}$ conducted on a group of parents of children with asthma, and also work by Wei Wei Lai, Tze Jui Goh, Tian Po Oei et al. ${ }^{7}$, who showed that parents raising children with ASD declare significantly many more symptoms of experienced stress, such as: a lower level of satisfaction with parent-child relations, negative self-presentation of parents, intense negative emotions emerging in relation to the presence of difficult behaviour of the child, and more symptoms of depression than parents of correctly developing children. Similar conclusions are provided by research of Agnieszka Dłużniewska and Kamil Kuracki8, who showed that parents of disabled children experience decidedly many more feelings such as disquiet, stress, loneliness and exhaustion, emerging in relation to disconcerting behaviour of their own child, as compared to parents of children developing correctly. It must be stated, however, that parents do not always see the difficult behaviour patterns of their children exclusively in the category of symptoms accompanying their disability or development dysfunc-

${ }^{5}$ M.Ch. Lovejoy, R. Weis, E. O'Hare, E.C. Rubin, Development and Initial Validation of the Parent Behavior Inventory, "Psychological Assessment' 1999, no. 11(4), pp. 534-545.

${ }^{6}$ M. Verkleij, E.J. van de Griendt, V. Colland, N. van Loey, A. Beelen, R. Geenen, Parenting Stress Related to Behavioral Problems and Disease Severity in Children with Problematic Severe Asthma, "Journal of Clinical Psychology in Medical Settings" 2015, no. 22, pp. 179-193.

7 W.W. Lai, T.J. Goh, T.P. Oei, M. Sung, Coping and Well-Being in Parents of Children with Autism Spectrum Disorders (ASD), "Journal of Autism \& Developmental Disorders" 2015, no. 45, pp. 2582-2593.

8 A. Dłużniewska, K. Kuracki, Parents' well-being and coping with problematic behavior of their child with disability, "10th International Conference on Education and New Learning Technologies. Conference Proceedings" 2018, no. 1, pp. 5039-5046. 
tions. As proven for instance by the qualitative research by Myrthe Jacobs, Lisa M. Woolfson and Simon C. Hunter 9 , conducted within a group of parents raising children with intellectual disabilities, parents relatively frequently perceive non-adaptive behaviour of their child as a result of their own unsuitable methods of upbringing as well as the influence of the environment. Hence, frequently, they notice long-term effects of shortcomings of their own work with the child, e.g. in terms of being consequent, patient, calm, self-certain; this includes spontaneous reactions to unwanted behaviour of the child and excess demands of them.

Despite the fact that the mode of perception of the child's disability and the entire life situation of the entire family system by the parents seems to be varied and dependent on many factors such as: the moment when the development difficulties are recognised; the type of disability of the child or the family financial situation ${ }^{10}$, etc., experiencing stress factors related to the prevailing life situation, with a lack of relevant resistance resources constituting protective factors may quite probably result with social isolation, loneliness or even fatigue syndromes emerging in the parents. Such consequences may in turn significantly translate to the quality of the relations between parents and their disabled children. They can in particular result in limited engagement of the parents in the establishment of proper relations with the child, as well as the emergence of parental behaviour that does not provide support. ${ }^{11}$ Stress related to a child with a disability or development dysfcuntions coming to the family

${ }^{9}$ M. Jacobs, L.M. Woolfson, S.C. Hunter, Attributions of Stability, Control and Responsibility: How Parents of Children with Intellectual Disabilities View their Child's Problematic Behaviour and Its Causes, "Journal of Applied Research in Intellectual Disabilities" 2016, no. 29, pp. 58-70.

10 A. Twardowski, Sytuacja rodzin dzieci niepetnosprawnych, [in:] Dziecko niepetnosprawne w rodzinie, ed. by I. Obuchowska, Wydawnictwa Szkolne i Pedagogiczne, Warszawa 2008, pp. 18-54.

${ }^{11} \mathrm{~K}$. Kuracki, A. Dłużniewska, Support for parents of children with disabilities and development of parent-child relationships, "10th International Conference on Education and New Learning Technologies. Conference Proceedings", no. 1, pp. 5032-5038. 
may also be related to the selection of a particular style of upbringing. ${ }^{12}$ For this reason, empirical studies usually indicate psychological constructs that may constitute for parents of disabled children potential factors of psychological resistance and factors predicting well-being. These include, among others, self-efficiency ${ }^{13}$, a positive attitude $^{14}$, acceptance ${ }^{15}$, awareness. ${ }^{16}$ As Hanna Kubiak pointed out 17 , a significant role of moderator in the course of coping processes with difficult situations in parents with cerebral palsy is also optimism, encouraging parents to select creative coping strategies. A factor protecting parents of children with disabilities is also hope that, according to assumptions of positive psychology, can be analysed as behaviour aimed at a specific goal. ${ }^{18}$

12 A. Twardowski, Wczesne wspomaganie rozwoju dzieci z niepetnosprawnościami w środowisku rodzinnym, Wydawnictwo UAM, Poznań 2012; S.A. Esdaile, K.M. Greenwood, A comparison of mothers' and fathers' experience of parenting stress and attributions for parent-child interaction outcomes, "Occupational Therapy International" 2003, no. 10(2), pp. 115-126; L.M. Woolfson, R.J. Taylor, L. Mooney, Parental attributions of controllability as a moderator of the relationship between developmental disability and behaviour problems, "Child: care, health and development" 2010, no. 37(2), pp. 184-194.

13 R.P. Hastings, T. Brown, Coping strategies and the impact of challenging behaviors on special educators' burnout, "Mental Retardation" 2002, no. 40, pp. 148-56; J.C. Kuhn, A.S. Carter, Maternal self-efficacy and associated parenting cognitions among mothers of children with autism, "American Journal of Orthopsychiatry" 2006, no. 76, pp. 564-75.

14 B.L. Baker, J. Blacher, M.B. Olsson, Preschool children with and without developmental delay: behaviour problems, parents' optimism and well-being, "Journal of Intellectual Disability Research" 2005, no. 49, pp. 575-590.

15 T.J. Lloyd, R.P. Hastings, Psychological variables as correlates of adjustment in mothers of children with intellectual disabilities: cross-sectional and longitudinal relationships, "Journal of Intellectual Disability Research" 2008, no. 52, pp. 37-48.

${ }^{16}$ N.N. Singh, G.E. Lancioni, A.S.W. Winton, B.C. Fisher, R.G. Wahler, K. McAleavey, Mindful parenting decreases aggression, noncompliance, and self-injury in children with autism, "Journal of Emotional and Behavioral Disorders" 2006, no. 14, pp. 169-77.

17 H. Kubiak, Optymizm jako czynnik wspomagajacy radzenie sobie ze stresem przez matki dzieci z mózgowym porażeniem, Wydawnictwo Naukowe UAM, Poznań 2012.

18 T.J. Lloyd, R.P. Hastings, Hope as a psychological resilience factor in mothers and fathers of children with intellectual disabilities, "Journal of Intellectual Disability Research" 2009, no. 53(12), pp. 957-968. 
An external resources that is important for the resistance and psychological flexibility of parents of children with disabilities and development dysfunctions is also broadly understood social suport ${ }^{19}$, defined, among others, as "a particular type of aid provided to individuals and groups mainly to mobilise their power, potential and resources that they have retained in order for them to be able to handle their problems" 20 , a type of social interaction undertaken by participants in difficult situations, as a result of which information, material goods or instruments of action are exchanged ${ }^{21}$, or as aid behaviour or aid available to an individual in difficult situations. ${ }^{22}$

${ }^{19}$ Issues concerning social aid for families of people with disabilities were described in Polish literature more broadly e.g. in: J. Kirenko, Wsparcie spoteczne rodzin $z$ dzieckiem niepetnosprawnym $i$ jego uwarunkowania, [in:] Rodzina: źródto życia $i$ szkota mitości, ed. by D. Kornas-Biela, Towarzystwo Naukowe KUL, Lublin 2000, pp. 385-393; A. Krause, Ryzyko ostabienia wsparcia społecznego jako podstawowy dylemat wspótczesnej rehabilitacji [in:] Wsparcie spoteczne w rehabilitacji i resocjalizacji, ed. by Z. Palak, Z. Bartkowicz, Wydawnictwo Uniwersytetu Marii Curie-Skłodowskiej, Lublin 2004, pp. 47-54; A. Maciarz, Znaczenie więzi i społecznego wsparcia w wypetnianiu rodzicielstwa wobec niepetnosprawnego dziecka, [in:] Watki zaniedbane, zaniechane, nieobecne $w$ procesie edukacji i wsparcia społecznego osób niepetnosprawnych, ed. by Z. Gajdzica, A. Klinik, Wydawnictwo UŚ, Katowice 2004, pp. 91-94; M. Parchomiuk, Sieć wsparcia spotecznego rodzin $z$ dzieckiem niepetnosprawnym, "Zeszyty Naukowe. Wyższa Szkoła Społeczno-Przyrodnicza im. Wincentego Pola w Lublinie" 2015, vol. 2, pp. 115-131; M. Sekułowicz, Problematyka funkcjonowania rodzin dzieci niepetnosprawnych, "Teraźniejszość-Człowiek-Edukacja” 1998, no. 1, pp. 61-8; B. Szluz, Wsparcie społeczne rodziny osoby niepetnosprawnej, „Roczniki Teologiczne” 2015, vol. LIV, issue 10, pp. 201-214; J. Wyczesany, Rodzaje wsparcia udzielanego rodzicom przez terapeutów w świetle ich wypowiedzi, [in:] Wspomaganie rozwoju dzieci z genetycznie uwarunkowanymi zespołami zaburzeń, ed. by J. Wyczesany, Stowarzyszenie na Rzecz Dzieci z Zaburzeniami Genetycznymi GEN, Poznań 2010, pp. 133-140; A. Żyta, K. Ćwirynkało, Wspieranie rodzin dzieci z niepetnosprawnościa - perspektywa zmiany, „Wychowanie w rodzinie" 2015, vol. XI, no. 1, pp. 377-396.

${ }^{20}$ Z. Kawczyńska-Butrym, Niepetnosprawność - specyfika pomocy społecznej, Wydawnictwo Naukowe Śląsk, Katowice 1998, p. 87.

${ }^{21} \mathrm{H}$. Sęk, Wsparcie społeczne - co zrobić aby stało się pojęciem naukowym, „Przegląd Psychologiczny", 1986, no. 3, pp. 791-800. In the current research project, social aid is understood primarily as social interactions in line with the presented psychological concept.

${ }^{22}$ T. Rostkowska, Małżenstwo, rodzina i praca a jakość życia, Oficyna Wydawnicza „Impuls", Kraków 2008, p. 53. 
Social sciences stress that this stems from the attitude of others towards that person and that it provides them, beside a good mood and the conviction that they can count on others, also with a feeling of security and belonging to a certain community. ${ }^{23}$ Social aid that is informative, instrumental, emotional or material or spiritual, ${ }^{24}$ stemming from various sources, may contribute not only to the parents' adaptation to the child's disability ${ }^{25}$, but also to the reduction of stress accompanying the education of a disabled child. ${ }^{26}$ As shown by studies of Brian A. Boyd ${ }^{27}$ conducted on a group of mothers of children with autism, a low level of satisfaction with the received social aid turned out to be a significant predictive factor both of depressive behaviour as well as of fear. Significant importance of social aid as well as of the feeling of coherence and internal control for the development of the ability of constructive coping with stress by parents of children with development dysfunctions was stressed among others in the work of Ayelet Siman-Tov and Shlomo Kaniel ${ }^{28}$ as well as Pilar Pozo and Encarnacion Sarriá. ${ }^{29}$ Moreover, according to the results of research by Mauricio Feldman, Linda McDonald, Lisa Serbin et al., 30 the experience by parents of children with au-

${ }^{23}$ G. Filipiak, Funkcja wsparcia społecznego w rodzinie, „Roczniki Socjologii Rodziny" 1991, no. XI, pp. 131-144.

${ }^{24}$ H. Sęk, R. Cieślak, Wsparcie społeczne, stres $i$ zdrowie, Polskie Wydawnictwo Naukowe, Warszawa 2005.

${ }_{25}$ M. Kościelska, Trudne macierzyństwo, Wydawnictwa Szkolne i Pedagogiczne, Warszawa, 1998.

${ }^{26}$ H.D. Luther, L.D. Canham, Y.V. Cureton, Coping and social support for parents of children with autism, "Journal of School Nursing" 2005, no. 21, pp. 40-47.

27 B.A. Boyd, Examining the relationship between stress and lack of social support in mothers of children with autism, "Focus on autism and other developmental disabilities" 2002, no. 17(4), pp. 208-215.

28 A. Siman-Tov, S. Kaniel (2011), Stress and personal resource as predictors of the adjustment of parents to autistic children: A multivariate model, "Journal of Autism and developmental Disorders", no. 41(7), pp. 879-890.

29 P. Pozo, E. Sarriá, Still stressed but feeling better: Well-being in autism spectrum disorder families as children become adults, "Autism" 2015, no. 19(7), pp. 805-813.

${ }^{30}$ M. Feldman, L. McDonald, L. Serbin, Predictors of depressive symptoms in primary caregivers of young children with or at risk for developmental delay, "Journal of Intellectual Disability Research" 2007, no. 51, pp. 606-619. 
tism of high levels of social aid can reduce negative effects that stress has on the behaviour of the mother during interaction with the child. At the same time, according to the assumptions of the transactional model, it may be assumed that satisfaction with the received social aid will most probably contribute to the reduction of rather unconstructive behaviour presented by parents of disabled children and to the intensification of supporting behaviour towards the child. ${ }^{31}$

Considering the significance of social aid for the well-being of parents raising children with special needs, one must stress the significant role of the parents making up formal and informal support networks and groups. Despite the fact that studies exist indicating limited significance of strong network bonds for the well-being of parents of children with development disabilities 32 , a significant part of them indicate high efficiency of aid in groups of parents of disabled children, who want to share their experiences with other parents in similar situations. ${ }^{33}$ The openness of parents to receive aid and the quality of the aid received may also significantly influence the engagement of parents in revalidation. As one may see in the analyses conducted by Agnieszka Sakowicz-Boboryko ${ }^{34}$, the

${ }^{31}$ B.L. Baker, L.L. McIntyre, J. Blacher, K. Crnic, C. Edelbrock, C. Low, Pre-school children with and without developmental delay: behaviour problems and parenting stress over time, "Journal of intellectual Disability Research" 2003, no. 47(4-5), pp. 217-230.

32 J. Khun, K. Ford, L.S. Dawalt, Brief report: Mapping system of support and psychological well-being of mother of adolescents with autism spectrum disorders, "Journal of Autism and Developmental Disorders" 2018, no. 48(3), pp. 940-946.

${ }^{33}$ S.M. Kerr, J.B. McIntosh, Coping when a child has a disability: exploring the impact of parent-to-parent support, "Child: Care, Health and Development" 2000, no. 26(4), p. 309-322; M. Phillips, Support groups for parents of chronically ill children, "Pediatric Nursing" 1990, no. 16, pp. 404-406; E.T. Matloff, S.J. Zimmerman, Framework for a proactive parents support group: the Syracuse cystic fibrosis model, "Journal of Pediatric Health Care" 1996, no. 10, pp. 264-271; B. Santelli, A. Turnbull, C. Higgins, Parent to parent support and health care, "Pediatric Nursing" 1997, no. 23, p. 303-306.

${ }^{34}$ A. Sakowicz-Boboryko, Wsparcie rodziców w rehabilitacji dzieci z niepetnosprawnościa stuchową. W kręgu odpowiedzialności, Wydawnictwo Akademickie Żak, Warszawa 2016. 
received social aid fulfils a significant function of support for rehabilitation activity of parents of children with development dysfunctions. Still, irrespective of the rouse of the social aid received, it is significant for parents of children with disabilities and development dysfunctions to experience social aid in line with their needs and expectations, as inadequate aid related e.g. to overprotectiveness in the support of others - reduces the adaptation capacities of the family. It may thus become a further burden ${ }^{35}$, disturbing the homoeostasis of the family system.

\section{Methodological assumptions of own research}

The objective of the conducted research was an exploration of the issue of satisfaction with social aid experienced by parents raising children with various kinds of disabilities, the exploration and comparison of the levels of supporting/ engaged and hostile/ compulsive parental behaviour and the levels of self-assessment of parental behaviour and the parental assessment of undesirable child behaviour in parents raising children with disabilities and parents of children without disabilities, as well as the determination of relations between the support experienced by parents raising children with disabilities and parental behaviour in the parent-child relation. ${ }^{36}$ The objective described in this way was aided by the following research questions:

1. What is the level of satisfaction with the social aid by medical facilities, therapists and family experienced by parents of children with disabilities?

35 A. Banasiak, Wsparcie społeczne a poziom doświadczanego stresu rodzicielskiego u ojców dzieci z zaburzeniami rozwoju, "Pedagogika rodziny. Family Pedagogy” 2014, no. 4, pp. 177-188.

36 The study was a pilot one and was conducted as part of the broader research project numbered BSTP 14/17-I entitled Behavioural problems of children with disabilities and the qualitative and quantitative dimension of aid received by parents, headed by Dr Agnieszka Dłużniewska and financed by The Maria Grzegorzewska University in Warsaw. 
2. What is the level of supportive/ engaged and hostile/ compulsive parental behaviour in parents of children with disabilities and of children without disabilities?

3. Do differences exist between the level of supportive/ engaged and hostile/ compulsive parental behaviour in parents raising children with disabilities and parents raising children without disabilities, and what are they?

4. Do differences exist between the level of self-assessment of parental behaviour and parental assessment of undesirable child behaviour in parents raising children with disabilities and parents of children without disabilities, and what are they?

5. Does there exist a relation between the experienced social aid on the one hand and the supportive/ engaged and hostile/ compulsive parental behaviour and the level of selfassessment of parental behaviour and the parental assessment of undesirable child behaviour on the other hand in parents raising children with disabilities, and what is it?

6. Does there exist a relation between supportive/ engaged and hostile/ compulsive parental behaviour and the level of selfassessment of the behaviour of parents and the parental assessment of undesirable behaviour of the child in parents raising children without disabilities, and what is it?

Due to the exploratory nature of the research, hypotheses were omitted from the project. The study uses the diagnostic survey method. The following questionnaires were used as research tools: the Parent Behavior Inventory by M. Christina Lovejoy, Robert Weis, Elizabeth O'Hare and Elizabeth C. Rubin ${ }^{37}$; the Parent Cognition Scale by Jeffery D. Snarr, Amy M. Smith Slep and Vincent P. Grande $^{38}$ and the questionnaire for parents as developed by Ag-

${ }^{37}$ M.Ch. Lovejoy, R. Weis, E. O'Hare, E.C. Rubin, Development and Initial Validation of the Parent Behavior Inventory, "Psychological Assessment" 1999, no. 11(4), pp. 534-545.

38 J.D. Snarr, A.M. Slep, and V.P. Grande, Validation of a New Self-Report Measure of Parental Attributions, "Psychological Assessment" 2009, no. 21(3), pp. 390-401. 
nieszka Dłużniewska. ${ }^{39}$ The Parent Behavior Inventory (PBI) is composed of 20 items and is used to assess parental behaviour in contact with the child, across two dimensions: hostile/ compulsive behaviour, understood as such that expresses a negative or indifferent attitude towards the child, and may encompass among others threats, physical punishment and forceful reactions to the child's needs, and supportive/ engaged behaviour, meaning, such that indicates acceptance of the child, expressed in, among others, undertaking common activities, expressing warm feelings towards them and assurance of emotional support. Each statement uses a six-degree Likert scale. Due to the translation of the tool into Polish, within the project, the executed study was analysed for test reliability, with high levels of Cronbach's Alpha found for both studied groups, both for the hostility / compulsion scale $(\alpha=0.85-0.86)$ as well as for the support/ engagement scale $(\alpha=0.69-0.82)$.

The Parent Cognition Scale (PCS) is composed of 30 items and is used to assess two factors: undesirable child behaviour (from the parent's point of view), such as: stubbornness, de, demanding, failure to submit to parental pleas, excess resistance, etc., and the self-assessment of parental behaviour in contact with the child, taking into account the level of perception by the parent of their own negative behaviour, e.g. lack of consequence in action, failure to give the child sufficient attention, difficulty setting boundaries for the child, lack of patience and self-certainty in contact with the child. The conducted reliability analysis showed high levels of Cronbach's Alpha for both groups: factor I ( $a=0.61-0.91)$, factor II $(\alpha=0.89-0.91)$.

The questionnaire for parents in turn is made up of 97 statements, and is foreseen for analysing satisfaction with the received feeling of aid (both from medical facilities, therapists and the family) that the parents have received from the moment of diagnosing of their child's disability, as well as parental expectations concerning the forms of support that they feel they should get. The tool shows

${ }^{39}$ K. Kuracki, A. Dłużniewska, op. cit. 
high levels of reliability ( $\alpha=0.96$ for the entire scale, $\alpha=0.94$ for the subscale of support by medical facilities, $\mathrm{a}=0.95$ for the subscale of support by therapists, $\mathrm{a}=0.87$ for the subscale of family support and $a=0.94$ for the subscale of expected support).

The conducted research assumed a purposeful-random sample selection. The research group was composed of 66 parents ( 49 women, 17 men) raising little children three to six years of age with various disabilities such as ASD, sight disability, Down syndrome, malformative syndrome and compound disability, and the control group consisted of 40 parents ( 28 women and 12 men) of children three to six years of age, developing correctly. The age of the analysed parents fit in between 25 to over 45 years. The study was conducted at preschools and early development support facilities in the Polish Masovian, Warmian-Masurian, Lower Silesian and Pomeranian voivodeships.

\section{Achieved results}

According to results presented in table 1 , in the subjective assessment of parents of children with disabilities, the decisively most satisfying source of support turns out to be the family ( $M=9.91$, $\mathrm{SD}=1.13$ ), which is indicated much more frequently than support received from therapists. Decidedly least satisfying is in turn support by medical facilities $(\mathrm{M}=2.30, \mathrm{SD}=1.35)$. Considering the sixgrade Likert scale assumed in the questionnaire (with one being "strongly disagree" and six being "strongly agree") one can assume that parental satisfaction with various sources of formal and informal aid received ranges low to average.

As shown in table 2, the mean level of hostile-compulsive behaviour represented by parents of children with disabilities $(M=2.21)$ does not differ significantly from the mean level of behaviour represented by parents of children without disabilities $(\mathrm{M}=3.38)$ $\left(t_{(103,52)}=-1.89, p>0.05\right)$. Similarly, the mean level of supportiveengaged behaviour represented by parents of children with disabili- 
ties $(M=4.30)$ also does not differ significantly from the mean level of behaviour represented by parents of children without disabilities $(\mathrm{M}=4.46)\left(\mathrm{t}_{(104)}=-1.08, \mathrm{p}>0.05\right)$.

Table 1. Assessment of satisfaction of parents of children with disabilities with the aid received $(\mathrm{N}=66)$

\begin{tabular}{|l|c|c|}
\hline \multicolumn{1}{|c|}{ Variable } & M & SD \\
\hline Aid by medical facilities & 2.3040 & 1.35127 \\
\hline Aid by therapists & 2.7763 & 1.15736 \\
\hline Aid by the family & 3.9072 & 1.12521 \\
\hline
\end{tabular}

Legend: M-arithmetic mean, SD-standard deviation

Source: Own research, work based upon SPSS 25.0.

Table 2. Differences in hostile/ compulsive and supportive/ engaged behaviour presented by parents of children with disabilities $(\mathrm{N}=66)$ and of children without disabilities $(\mathrm{N}=40)$

\begin{tabular}{|l|c|c|c|c|c|c|c|}
\hline \multirow{2}{*}{ Variable } & \multicolumn{2}{|c|}{$\begin{array}{c}\text { Parents of children } \\
\text { with disabilities }\end{array}$} & \multicolumn{2}{c|}{$\begin{array}{c}\text { Parents of children } \\
\text { without disabilities }\end{array}$} & $\mathrm{t}$ & $\mathrm{Df}$ & $\mathrm{p}$ \\
\cline { 2 - 9 } & $\mathrm{M}$ & $\mathrm{SD}$ & $\mathrm{M}$ & $\mathrm{SD}$ & & & \\
\hline $\begin{array}{l}\text { Hostile/ compul- } \\
\text { sive behaviour }\end{array}$ & 2.21 & 0.788 & 2.38 & 0.816 & -1.885 & 103.518 & 0.062 \\
\hline $\begin{array}{l}\text { Supportive/ en- } \\
\text { gaged behaviour }\end{array}$ & 4.30 & 0.521 & 4.46 & 0.336 & -1.083 & 104 & 0.281 \\
\hline
\end{tabular}

Legend: M-arithmetic mean, SD-standard deviation, t-Student's t-test value, Df-degrees of freedom, p-significance.

Source: Own research, work based upon SPSS 25.0.

The obtained results suggest the conclusion that parents of children with special needs, similarly to parents of children with no discerned developmental deviations, present behaviour supporting the child as well as such that indicates parental attitudes providing little support. It seems thus that a child's disability does not constitute a factor differentiating parental behaviour in contact with the child. 
Statistical analysis using Student's t-test for dependent samples (Table 3) indicates that the assessment of undesirable behaviour of children by parents of children with disabilities $(M=34.71)$ does not differ significantly from the assessment made by parents of children without disabilities $(\mathrm{M}=36.30)\left(\mathrm{t}_{(104)}=-1.04, \mathrm{p}>0.05\right)$. Moreover, the study did not show statistically significant differences between both parent groups in terms of the self-assessment of own behaviour.

Table 3. Differences in the mean scores of parents of children with disabilities $(\mathrm{N}=66)$ and of children without disabilities $(\mathrm{N}=40)$ with respect to the assessment of children's behaviour and the self-assessment of own behaviour

\begin{tabular}{|l|c|c|c|c|c|c|c|}
\hline \multirow{2}{*}{ Variable } & \multicolumn{2}{|c|}{$\begin{array}{c}\text { Parents of } \\
\text { children with } \\
\text { disabilities }\end{array}$} & \multicolumn{2}{|c|}{$\begin{array}{c}\text { Parents of } \\
\text { children without } \\
\text { disabilities }\end{array}$} & $\mathrm{t}$ & Df & $\mathrm{p}$ \\
\cline { 2 - 6 } & $\mathrm{M}$ & $\mathrm{SD}$ & $\mathrm{M}$ & $\mathrm{SD}$ & & & \\
\hline $\begin{array}{l}\text { Child Responsible } \\
\text { (child behaviour as- } \\
\text { sessment) }\end{array}$ & 34.71 & 7.198 & 36.30 & 8.290 & 1.039 & 104 & 0.301 \\
\hline $\begin{array}{l}\text { Parent Causal (parent } \\
\text { behaviour self-as- } \\
\text { sessment) }\end{array}$ & 30.681 & 4.843 & 31.575 & 5.368 & 0.883 & 104 & 0.379 \\
\hline
\end{tabular}

Legend: $\mathrm{M}$ - arithmetic mean, SD - standard deviation, $\mathrm{t}$ - Student's t-test value, Df - degrees of freedom, $\mathrm{p}$ - significance

Source: Own research, work based upon SPSS 25.0.

Attempting to determine the relations between the aid received by parents raising children with disabilities and the supportive/ engaged, hostile/ compulsive behaviour patterns presented by them in contact with the child, and the self-assessment of parental behaviour along with the parental assessment of undesirable child behaviour, the study tested Pearson's r. According to data contained in table 4 , the analyses showed significant moderate correlations between the self-assessment of parental behaviour and the assessment of child behaviour $(\mathrm{r}=0.53, \mathrm{p}<0.01)$, indicating that as parents' satisfaction with their own behaviour towards the child 
improves, the positive assessment of the behaviour of the child themselves improves along. Low assessment of own parental behaviour is in turn related to parents perceiving decidedly more symptoms of improper behaviour in their children.

Table 4. Pearson's r. of the tested variables: Social aid received by parents - by medical facilities, therapists, the family, supportive-engaged behaviour, hostilecompulsive behaviour, and the assessment of the behaviour of the child and selfassessment of parental behaviour in the group of parents of children with disabilities $(\mathrm{N}=66)$

\begin{tabular}{|l|c|c|c|c|c|c|}
\hline \multicolumn{1}{|c|}{ Variables } & 1 & 2 & 3 & 4 & 5 & 6 \\
\hline $\begin{array}{l}\text { 1. Parent causal } \\
\text { (parent behaviour self- } \\
\text { assessment) }\end{array}$ & $0.531^{* *}$ & & & & & \\
\hline $\begin{array}{l}\text { 2. Child responsible } \\
\text { (child behaviour as- } \\
\text { sessment) }\end{array}$ & 0.229 & 0.011 & & & & \\
\hline $\begin{array}{l}\text { 3. Supportive-engaged } \\
\text { behaviour }\end{array}$ & $-0.591^{* *}$ & $-0.336^{* *}$ & 0.054 & & & \\
\hline $\begin{array}{l}\text { 4. Hostile-compulsive } \\
\text { behaviour }\end{array}$ & -0.080 & 0.013 & -0.174 & 0.126 & & \\
\hline 5. Aid by medical facilities & -0.100 & -0.074 & -0.161 & 0.080 & $\mathbf{0 . 7 4 8 * *}$ & \\
\hline 6. Aid by therapists & -0.105 & & & \\
\hline 7. Aid by the family & -0.114 & -0.141 & 0.065 & 0.185 & $\mathbf{0 . 4 5 9 * *}$ & $0.276^{*}$ \\
\hline
\end{tabular}

Legend: ** correlation significance at $\mathrm{p}<0.01{ }^{*}$ correlation significance at $\mathrm{p}<0.05$

Source: Own research, work based upon SPSS 25.0.

The analyses also showed negative moderate correlations between parent compulsive/ hostile behaviour and the self-assessment of their behaviour towards the children $(\mathrm{r}=-0.59, \mathrm{p}<0.01)$. The more unfavourable behaviour instances towards own children expressed by parents, the worse do they evaluate their own behaviour. Statistically significant weak negative correlations were also found between hostile/ compulsive parental behaviour and the parental assessment of child behaviour $(\mathrm{r}=0.34, \mathrm{p}<0.01)$. Hence, the more 
unfavourable behaviour towards the child expressed by parents, meaning, the more frequently they do not show sufficient attention, they lose control when in contact with the child or they tell them things that could hurt them, the worse to they assess their behaviour.

The obtained scores could indicate self-reflection by parents and their awareness of the consequences of their own actions with respect to the shaping of attitudes and behaviour of the child and the establishment of proper relations with them. The conducted analyses did not show the presence of a significant relationship between the assessment of aid received by parents and their expressed behaviour in terms of support/ engagement and hostility/ compulsion towards the child. No significant relations were also found between parental assessment of the received aid and self-assessment of parental behaviour and the parental assessment of child behaviour.

Significant moderate and strong positive correlations are in turn found between the subjective perception by parents of aid by medical facilities and the experience of aid by therapists $(r=0.75, p<0.01)$ and by the family $(\mathrm{r}=0.46, \mathrm{p}<0.01)$. Weak moderate positive correlations were finally found between support by the family and support by therapists $(r=0.28, p<0.05)$. The obtained results could hint that the better the assessment by parents of children with disabilities of their experience of various forms of aid by medical facilities, the better they assess the quality of aid provided by specialists working with the child and the higher level of satisfaction they experience from support provided by their closest ones. Moreover, satisfaction with aid provided by the family also improves in parents of children with special needs, along with positive experiences in terms of aid received from therapists.

Siilarly to parents raising children with disabilities, the group of parents of children without disabilities also expressed strong positive correlations between the self-assessment of parental behaviour and the assessment of the child's bebaviour $(\mathrm{r}=0.78, \mathrm{p}<0.01)$ (Table 5). 
Table 5. Correlations (Pearson's r.) of tested variables: parent behaviour self-assessment, child behaviour assessment, supportive-engaged behaviour and hostile-compulsive behaviour in the group of parents of children without disabilities $(\mathrm{N}=40)$

\begin{tabular}{|l|c|c|c|}
\hline \multicolumn{1}{|c|}{ Variables } & 1 & 2 & 3 \\
\hline $\begin{array}{l}\text { 1. Parent causal } \\
\text { (parent behaviour self-assessment) }\end{array}$ & & & \\
\hline $\begin{array}{l}\text { 2. Child responsible } \\
\text { (child behaviour assessment) }\end{array}$ & $\mathbf{0 , 7 7 8 ^ { * * }}$ & & \\
\hline 3. Supportive-engaged behaviour & 0.189 & -0.017 & \\
\hline 4. Hostile-compulsive behaviour & $\mathbf{- 0 . 4 5 6 ^ { * * }}$ & $\mathbf{- 0 . 5 1 ^ { * * }}$ & -0.012 \\
\hline
\end{tabular}

Legend: ** correlation significance at $\mathrm{p}<0,01$ * correlation significance at $\mathrm{p}<0,05$ Source: Own research, work based upon SPSS 25.0.

On the basis of the conducted analysis, one could conclude on finding in this group of respondents significant relations between hostile/ compulsive behaviour and self-assessment of parental behaviour $(\mathrm{r}=-0.456, \mathrm{p}<0.01)$ and the parental assessment of the child's behaviour $(\mathrm{r}=-0.51, \mathrm{p}<0.01)$.

\section{Discussion of results and conclusions}

The conducted research project saw an attempt at assessing the satisfaction of parents raising children with disabilities with the aid they receive and the relation between the aid received on the one hand and the diversity of parental behaviour patterns towards the child. The achieved results allow the observation that parents raising children with disabilities and development dysfunctions experience aid from various sources, the most important of which seems to be the family, with the least satisfying one being medical facilities. Similar data is provided, e.g., by studies of Janusz Kirenko ${ }^{40}$, which stress that the best source of aid for families raising children with disabilities are persons of significance, meaning, the closest

${ }^{40} \mathrm{~J}$. Kirenko, op. cit. 
family, the spouse, friends. The acquired aid, as assessed by parents, is, however, insufficient, as proven, among others, by quite low parental satisfaction scores with the aid received. These results correspond with other studies, e.g. by Agnieszka Żyta and Katarzyna Ćwirynkało ${ }^{41}$, who showed in the conducted qualitative analyses of interviews with parents of children with intellectual disabilities many discernible shortcomings, in terms of support offered to them and stemming from various sources. It thus seems that despite the fact that parents raising disabled children are frequently able to precisely describe their needs in terms of the resources that they would like to receive both from their closest environment, medical, educational and therapeutic facilities, or even the state's social poli$\mathrm{cy}$, there exists great disparity between the needs of the family and their satisfaction. Studies also suggest one more conclusion: As parental satisfaction grows with aid received from one source, the satisfaction also improves with aid received from other sources. This state of affairs may constitute the impetus for considerations on the need to develop a comprehensive aid system for families raising children with disabilities and development dysfunctions, allowing e.g. the parents to acquire exhaustive information on the child's health, the functional diagnosis and institutional forms of aid, the discussion of diverse pathways of the further education of the child, the determination, together with specialists, of the plan of medical treatment, revalidation, rehabilitation, discussion of any sort of extended diagnosis of prognosis, participation in instruction and psychoeducation seminars organised for parents concerning, for instance, the recommended methods and forms of work with the child and countering their difficult behaviour.

It is very probable that the lack of parental experience of satisfactory social aid may substantiate results suggesting the lack of relationship between the assessment of aid and the parental behaviour expressed in contact with the child and the self-assessment of parental behaviour as well as the parental assessment of unwanted behaviour of the child. On the basis of the conducted analysis of

${ }^{41}$ A. Żyta, K. Ćwirynkało, op. cit. 
studies ${ }^{42}$ one could thus conclude that satisfaction with the received aid will be a significant predictor for constructive coping by parents with difficult situations, and a factor reinforcing parental wellbeing. One could thus expect for satisfaction from the received aid to be directly translated to the reduction of parental behaviour along the scale of hostility/ compulsion and intensification of supportive/ engaged behaviour.

The studies did not show significant differences between parents raising disabled children and parents of children without disabilities, in terms of the levels of presented supportive/ engaged, supportive/ hostile behaviour, as well as in terms of the assessment of child behaviour and self-assessment of own behaviour in the relation with the child. It may be that it is not the child's disability but other psychological or environmental factors determine specific actions of the parents towards their children. The lack of relations between the subjective assessment of the experienced aid and parental behaviour towards children may also be the result of the study group for the conducted pilot project being too limited. Perhaps this is also the reason why the study did not find significant differences between the bahaviour of parents of disabled children and prents of children without disabilities, which is surprising due to the results of research discussed earlier on the psychological strength of parents of children with disabilities.

According to the achieved results, both the group of parents of children with disabilities as well as of children developing correctly, see, along with an improvement of the assessment of their own behaviour towards the child, improvements in child behaviour assessment as perceived by the parent. The more constructive behaviour towards the child expressed by parents, meaning, the more frequently do they express warm feelings towards the child, spend free time together, listen to it, praise it, provide it with attention, etc., the more frequently do they notice positive changes in the

${ }^{42}$ B.L. Baker, L.L. McIntyre, J. Blacher, K. Crnic, C. Edelbrock, C. Low, op. cit.; B.A. Boyd, op. cit.; H.D. Luther, L.D. Canham, Y.V. Cureton, op. cit.; P. Pozo, E. Sarriá, op. cit.; A. Siman-Tov, S. Kaniel, op. cit. 
child's behaviour. The inefficiency of unconstructive parental behaviour is also confirmed by the significant negative moderate correlations between hostile-compulsive behaviour by parents and the parental assessment of the child's behaviour as found by the study, indicating that the more hostile-compulsive behaviour towards the child expressed by parents, the worse do they assess the child's behaviour. The optimistic conclusion from the conducted project is the fact that the analysed parents seem to offer quite a high level of self-reflection. The study has found significant negative moderate correlations between compulsive/ hostile behaviour of parents and the self-assessment of their behaviour towards the child, indicating that the more unconstructive behaviour towards the child is expressed by parents, the worse their assessment of their own behaviour, with the parents frequently noticing lack of consequence, patience, engagement in their work with the child - with all of these failing to provide advantageous education results. These results correspond with results achieved in the studies of Myrthe Jacobs, Lisa M. Woolfson and Simon C. Hunter. ${ }^{43}$

The conducted research show the need of suitable preparation of personnel of medical facilities as well as therapists spanning the provision of emotional, information and instrumental aid to parents of children with special needs. The developed activities should take into account both systemic family resources as well as internal psychological resources of parents. It also seems logical to undertake further, deeper studies that could amend the missing area of nescience, e.g. in terms of predictors of parental behaviour that determine the parent-child relation.

\section{Bibliography}

[1] Baker B.L., McIntyre L.L., Blacher J., Crnic K., Edelbrock C., Low C. Pre-school children with and without developmental delay: behavior problems and parenting stress over time, "Journal of intellectual Disability Research" 2003, no. 47(4-5), pp. 217-230.

${ }^{43}$ M. Jacobs, L.M. Woolfson, S.C. Hunter, op. cit. 
[2] Baker B.L., Blacher J., Olsson M.B., Preschool children with and without developmental delay: behavior problems, parents' optimism and well-being, "Journal of Intellectual Disability Research" 2005, no. 49, pp. 575-590.

[3] Banasiak A., Wsparcie społeczne a poziom doświadczanego stresu rodzicielskiego u ojców dzieci z zaburzeniami rozwoju, "Pedagogika rodziny. Family Pedagogy" 2014, no. 4, pp. 177-188.

[4] Boyd B.A., Examining the relationship between stress and lack of social support in mothers of children with autism, "Focus on autism and other developmental disabilities" 2002, no. 17(4), pp. 208-215.

[5] Davis N.O., Carter A.S., Parenting stress in mothers and fathers of toddlers with autism spectrum disorders: Associations with child characteristic, "Journal of Autism and Developmental Disorders" 2008, no. 38(7), pp. 1278-1291.

[6] Dłużniewska A., Kuracki K., Parents' well-being and coping with problematic behavior of their child with disability, "10th International Conference on Education and New Learning Technologies. Conference Proceedings" 2018, no. 1, pp. 5039-5046.

[7] Eisenhower A., Baker B., Blacher J., Preschool children with intellectual disability: syndrome specificity, behaviour problems, and maternal well-being, "Journal of Intellectual Disability Research" 2005, no. 49(9), pp. 657-671.

[8] Esdaile A.S., Greenwood K.M., A comparison of mothers' and fathers' experience of parenting stress and attributions for parent-child interaction outcomes, "Occupational Therapy International" 2003, no. 10 (2), p. 115-126

[9] Estes A., Munson J., Dawson G., Koehler E., Zhou X.H., Abbot R., Parenting stress and psychological functioning among mothers of preschool children with autism and developmental delay, "Autism" 2009, no. 13(4), pp. 375-387.

[10] Feldman M., McDonald L., Serbin L., Predictors of depressive symptoms in primary caregivers of young children with or at risk for developmental delay, "Journal of Intellectual Disability Research" 2007, no. 51, pp. 606-619.

[11] Filipiak G., Funkcja wsparcia społecznego w rodzinie, „Roczniki Socjologii Rodziny" 1991, no. XI, pp. 131-144.

[12] Ghasempour A., Akbari E., Taghipour M., Azimi Z., Refaghat E., Comparison of psychological well-being and coping styles in mothers of deaf and normally-hearing children, "Audiology" 2012, no. 21(4), pp. 51-59.

[13] Hastings R.P., Brown T., Coping strategies and the impact of challenging behaviors on special educators' burnout, "Mental Retardation" 2002, no. 40, p. 148-56.

[14] Jacobs M., Woolfson L.M., Hunter S.C., Attributions of Stability, Control and Responsibility: How Parents of Children with Intellectual Disabilities View their Child's Problematic Behaviour and Its Causes, "Journal of Applied Research in Intellectual Disabilities" 2016, no. 29, pp. 58-70.

[15] Kawczyńska-Butrym Z., Niepetnosprawność - specyfika pomocy społecznej, Wydawnictwo Naukowe Śląsk, Katowice 1998. 
[16] Kuhn J.C., Carter A.S., Maternal self-efficacy and associated parenting cognitions among mothers of children with autism, "American Journal of Orthopsychiatry" 2006, no. 76, pp. 564-575.

[17] Kuhn J., Ford K., Dawalt L.S., Brief report: Mapping system of support and psychological well-being of mother of adolescents with autism spectrum disorders, "Journal of Autism and Developmental Disorders" 2018, no. 48(3), pp. 940-946.

[18] Kerr S.M., McIntosh J.B., Coping when a child has a disability: exploring the impact of parent-to-parent support, "Child: Care, Health and Development" 2000, no. 26(4), pp. 309-322.

[19] Kirenko J., Wsparcie społeczne rodzin z dzieckiem niepetnosprawnym $i$ jego uwarunkowania, [in:] Rodzina: źródło życia i szkoła miłości, ed. by D. Kornas-Biela, Towarzystwo Naukowe KUL, Lublin 2000, pp. 385-393.

[20] Koperski Ł., Rodzina dziecka z niepetnosprawnościa a wsparcie społeczne, [in:] Zasoby rodziny. Wychowanie, Poradnictwo, Praca socjalna, ed. by E. Czerka-Fortuna, K. Kmita-Zaniewska, A. Zbierzchowska, Wydawnictwo Naukowe Katedra, Gdańsk 2016, pp. 156-177.

[21] Kościelska M., Trudne macierzyństwo, Wydawnictwa Szkolne i Pedagogiczne, Warszawa, 1998.

[22] Krause A., Ryzyko ostabienia wsparcia społecznego jako podstawowy dylemat wspótczesnej rehabilitacji. [in:] Wsparcie spoteczne $w$ rehabilitacji $i$ resocjalizacji, ed. by Z. Palak, Z. Bartkowicz, Wydawnictwo Uniwersytetu Marii Curie-Skłodowskiej, Lublin 2004, pp. 47-54.

[23] Kubiak H., Optymizm jako czynnik wspomagający radzenie sobie ze stresem przez matki dzieci z mózgowym porażeniem, Wydawnictwo Naukowe UAM, Poznań 2012.

[24] Kuracki K., Dłużniewska A., Support for parents of children with disabilities and development of parent-child relationships, "10th International Conference on Education and New Learning Technologies. Conference Proceedings", no. 1, pp. 5032-5038.

[25] Lai W.W., Goh T.J., Oei T.P., Sung M., Coping and Well-Being in Parents of Children with Autism Spectrum Disorders (ASD), "Journal of Autism \& Developmental Disorders" 2015, no. 45, pp. 2582-2593.

[26] Lloyd T.J., Hastings R.P., Psychological variables as correlates of adjustment in mothers of children with intellectual disabilities: cross-sectional and longitudinal relationships, "Journal of Intellectual Disability Research" 2008, no. 52, p. 37-48.

[27] Lloyd T.J., Hastings R.P., Hope as a psychological resilience factor in mothers and fathers of children with intellectual disabilities, "Journal of Intellectual Disability Research" 2009, no. 53(12), pp. 957-968.

[28] Lovejoy M.Ch, Weis R., O'Hare E., Rubin E.C., Development and Initial Validation of the Parent Behavior Inventory, "Psychological Assessment” 1999, no. 11(4), pp. 534-545. 
[29] Luther H.D., Canham L.D, Cureton V.Y., Coping and social support for parents of children with autism, "Journal of School Nursing" 2005, no. 21, pp. 40-47.

[30] Maciarz A., Znaczenie więzi $i$ społecznego wsparcia w wypetnianiu rodzicielstwa wobec niepetnosprawnego dziecka, [in:] Watki zaniedbane, zaniechane, nieobecne w procesie edukacji $i$ wsparcia spotecznego osób niepetnosprawnych, ed. by Z. Gajdzica, A. Klinik, Wydawnictwo UŚ, Katowice 2004, pp. 91-94.

[31] Matloff E.T., Zimmerman S.J., Framework for a proactive parents support group: the Syracuse cystic fibrosis model, "Journal of Pediatric Health Care" 1996, no. 10, pp. 264-271.

[32] Parchomiuk M., Sieć wsparcia społecznego rodzin z dzieckiem niepetnosprawnym, „Zeszyty Naukowe. Wyższa Szkoła Społeczno-Przyrodnicza im. Wincentego Pola w Lublinie" 2015, vol. 2, pp. 115-131.

[33] Phillips M., Support groups for parents of chronically ill children, „Pediatric Nursing" 1990, no. 16, pp. 404-406.

[34] Pisula E. Noińska D., Stres rodzicielski i percepcja doświadczeń związanych z opieka nad dzieckiem u rodziców dzieci $z$ autyzmem uczestniczacych w różnych formach terapii, „Psychologia rozwojowa” 2011, no. 3, pp. 75-88.

[35] Pozo P, Sarriá E., Still stressed but feeling better: Well-being in autism spectrum disorder families as children become adults, „Autism” 2015, no. 19(7), pp. 805-813.

[36] Rostkowska T., Małżeństwo, rodzina i praca a jakość życia, Oficyna Wydawnicza „Impuls”, Kraków 2008.

[37] Santelli B., Turnbull A., Higgins C., Parent to parent support and health care, "Pediatric Nursing" 1997, no. 23, p. 303-306.

[38] Sakowicz-Boboryko A., Wsparcie rodziców w rehabilitacji dzieci z niepetnosprawnością stuchową. W kręgu odpowiedzialności, Wydawnictwo Akademickie Żak, Warszawa 2016.

[39] Sekułowicz M., Problematyka funkcjonowania rodzin dzieci niepetnosprawnych, „Teraźniejszość-Człowiek-Edukacja” 1998, no. 1, pp. 61-78.

[40] Seymour M., Wood C.E., Giallo R., Jellett R., Fatigue, Stress and Coping in Mothers of Children with an Autism Spectrum Disorder, "Journal of Autism \& Developmental Disorders" 2013, no. 43, pp. 1547-1554.

[41] Sęk H., Wsparcie spoteczne - co zrobić aby stato się pojęciem naukowym, „Przegląd Psychologiczny", 1986, no. 3, pp. 791-800.

[42] Sęk H., Cieślak R., Wsparcie społeczne, stres $i$ zdrowie, Polskie Wydawnictwo Naukowe, Warszawa 2005.

[43] Silva L.M., Schalock M., Autism parenting stress index: Initial psychometric evidence, "Journal of Autism and Developmental Disorders" 2012, no. 42(4), pp. 566-574

[44] Siman-Tov A., Kaniel, S. (2011), Stress and personal resource as predictors of the adjustment of parents to autistic children: A multivariate model, "Journal of Autism and developmental Disorders", no. 41(7), pp. 879-890. 
[45] Singh N.N., Lancioni G.E., Winton A. S., Fisher B.C., Wahler R.G., McAleavey K., Mindful parenting decreases aggression, noncompliance, and self-injury in children with autism, "Journal of Emotional and Behavioral Disorders" 2006, no. 14, pp. 169-77.

[46] Snarr J.D., Slep A.M., and Grande V.P., Validation of a New Self-Report Measure of Parental Attributions, "Psychological Assessment" 2009, no. 21(3), pp. 390-401.

[47] Smith L.E., Seltzer M.M., Tager-Flusberg H., Greenberg J.S., Carter A.S., A Comparative Analysis of Well-Being and Coping among Mothers of Toddlers and Mothers of Adolescents with ASD, "Journal of Autism and Developmental Disorders" 2008, no. 38(5), pp. 876-889.

[48] Szluz B., Wsparcie społeczne rodziny osoby niepetnosprawnej, „Roczniki Teologiczne" 2015, vol. LIV, issue. 10, pp. 201-214.

[49] Twardowski A., Sytuacja rodzin dzieci niepetnosprawnych, [in:] Dziecko niepetnosprawne w rodzinie, ed. by I. Obuchowska, Wydawnictwa Szkolne i Pedagogiczne, Warszawa 2008, pp. 18-54.

[50] Twardowski A., Wczesne wspomaganie rozwoju dzieci z niepetnosprawnościami w środowisku rodzinnym, Wydawnictwo UAM, Poznań 2012

[51] Verkleij M., van de Griendt E. J., Colland V., van Loey N., Beelen A., Geenen R., Parenting Stress Related to Behavioral Problems and Disease Severity in Children with Problematic Severe Asthma, "Journal of Clinical Psychology in Medical Settings" 2015, no. 22, pp. 179-193.

[52] Woolfson L.M., Taylor R.J., Mooney L., Parental attributions of controllability as a moderator of the relationship between developmental disability and behaviour problems, "Child: care, health and development" 2010, no. 37(2), pp. 184-194.

[53] Wyczesany J., Rodzaje wsparcia udzielanego rodzicom przez terapeutów w świetle ich wypowiedzi, [in:] Wspomaganie rozwoju dzieci z genetycznie uwarunkowanymi zespołami zaburzeń, ed. by J. Wyczesany, Stowarzyszenie na Rzecz Dzieci z Zaburzeniami Genetycznymi GEN, Poznań 2010, pp. 133-140.

[54] Żyta A., Ćwirynkało K., Wspieranie rodzin dzieci z niepetnosprawnościa - perspektywa zmiany, „Wychowanie w rodzinie” 2015, vol. XI, no. 1, pp. 377-396. 